\title{
Yield of Brachiaria in Function of Natural Phosphate Application and Liming in Pará Northeast
}

\author{
Vanessa dos S. Araujo ${ }^{1}$, Katia C. B. Rodrigues ${ }^{1}$, Jessivaldo R. Galvão ${ }^{1}$, Tiago K. M. Yakuwa ${ }^{1}$, Vicente F. A. Silva ${ }^{1}$, \\ Deivison R. da Silva ${ }^{1}$, Leonardo B. Araújo ${ }^{1}$, Francisco J. L. de Souza ${ }^{1} \&$ Joel C. de Souza $^{1}$ \\ ${ }^{1}$ Institute of Agricultural Sciences, Universidade Federal Rural da Amazônia, Belém, Pará, Brazil \\ Correspondence: Jessivaldo R. Galvão, Institute of Agricultural Sciences, Universidade Federal Rural da \\ Amazônia, Soil Department, Tancredo Neves, No 2501, Montese, Belém, Pará, Brazil. Tel: 55(91)-98842-1133. \\ E-mail: jessigalvao50@gmail.com
}

$\begin{array}{lcc}\text { Received: April 2, } 2018 & \text { Accepted: May 11, } 2018 \quad \text { Online Published: June 15, } 2018 \\ \text { doi:10.5539/jas.v10n7p352 } & \text { URL: https://doi.org/10.5539/jas.v10n7p352 }\end{array}$

\begin{abstract}
Forage plants of the genus Brachiária show excellent adaptation to poor soils with high acidity in the region. They present good response to phosphate fertilization and tolerant to soil with higher humidity. The soils of Amazonia are characterized mainly by high acidity, low availability of phosphorus and high saturation of aluminum. Under these conditions, aluminum tends to fix the phosphorus, making it necessary to apply higher doses to supply the need for fodder, justifying the need to apply corrective acidity material. The objective was to evaluate the $\mathrm{pH}$ of the behavior and productivity of Brachiaria brizantha cv. Xaraés by using Arad rock phosphate and limestone dolomite in a yellow Latosol of medium texture collected from the 0-20 cm layer. The treatments were: soil only (T1); soil with the addition of lime (T2); soil with added Arad 30 days before planting (T3); soil with the addition of Arad on planting (T4); soil with the addition of Arad and liming 30 days before planting (T5); and soil with the addition of Arad and liming on planting (T6), distributed in five replications, totaling 30 experimental units. At 45 days of germination, evaluated the plant height (HP) and number of leaves $(\mathrm{NL})$, culminating with the courts to obtain the shoot fresh matter (SFM) and dry matter (FDM), the other cuts made every 30 days. $\mathrm{pH}$ variations responded positively to the treatments using lime to increase the $\mathrm{pH}$ to levels close to 6.5. For HP variables, NL, SFM and SDM the highest increases were obtained for treatments under the influence of limestone (T2) and limestone + Arad 30 days before planting (T5). The natural phosphate fertilizer in combination with liming showed significant results for all parameters.
\end{abstract}

Keywords: limestone, phosphorus, acidity, Brachiaria brizantha cv. Xaraés

\section{Introduction}

Grasses from Brachiaria genus comprise about 90 species of great morphological and phenological variety (Alves et al., 2015). They are mainly used in pasture formation in tropical America and own a position among most planted crops in Brazil, used in all stages of cattle raising (Ferreira \& Zazine, 2007).

B. brizantha $\mathrm{cv}$. Xaraés tolerates prolonged droughts, an important feature for regions that go through drought periods, has good recovery after burning and good regrowth ability, is susceptible to frost. It has a good tolerance to the grasshopper, it has more palatability than other brachiaria (Alves et al., 2015). According to Corrêa (2002), it presents excellent adaptation to poor soils with high acidity in the region. However, it presents a good response to phosphate fertilization and has a higher tolerance to humid soils compared to other $B$. brizantha cultivars (Valle et al., 2004). Nevertheless, Amazonian soils are mostly characterized by high acidity, low P availability and high aluminum saturation. In this situation the plants usually present symptoms of phosphorus deficiency, since aluminum fixes the phosphorus in less Available in soil and root surface, and interferes with the absorption, transport and use of phosphorus, among other essential elements, making it necessary to apply higher doses in order to nutritionally supply the need for forage crops (Costa, 2004). This justifies the need for the application of corrective acidity material, such as lime.

Liming increases the sum of bases (SB), raises nutrient availability and increases the exchange complex, saturates the exchange complex with calcium and magnesium, and raises the $\mathrm{pH}$ to a level where $\mathrm{Al}$ becomes virtually unavailable for crops (Ronquim, 2010). In a study of Brachiaria brizantha cv. Xaraés on a clayey Yellow Oxisol, 
Costa et al. (2012), obtained the maximum yield of dry mass when evaluating four different levels of liming, obtained high levels of phosphorus, calcium and magnesium due to limestone levels.

The use of natural phosphates, such as Arad, is an efficient alternative in decreasing the P fixation or deficiency in soils, since these have as main characteristic the gradual solubilization, tending to increase the $\mathrm{P}$ availability for the plants with the Time (Kaminski \& Peruzo, 1997).

Natural phosphates are derived from ground phosphate rock, which may or may not undergo physical processes of concentration (Fontoura et al., 2010). Guedes et al. (2009) states that reactive natural phosphate is a phosphate of low solubility. However, such fertilizer has been widely used in pasture fertilization, as it is also capable of increasing Brachiaria brizantha fodder production in comparison to sources of more soluble and more reactive $\mathrm{P}_{2} \mathrm{O}_{5}$, such as triple superphosphate, Arad in its composition provides around $30 \%$ of $\mathrm{P}_{2} \mathrm{O}_{5}$ and $37 \%$ of $\mathrm{CaO}$ in the soil.

The use of natural phosphates for the purpose of recovery or renewal of degraded pastures has been very promising, some studies have demonstrated positive effect that the use of these natural fertilizers has manifested (Guedes et al., 2009; Teixeira et al., 2014). The objective was to evaluate the behavior of $\mathrm{pH}$ and productivity of Brachiaria brizantha cv. Xaraés using Arad's natural phosphate and dolomitic limestone on a medium texture yellow latosol.

\section{Material and Methods}

\subsection{Research Methodology}

The experiment was carried out in a greenhouse at the Institute of Agricultural Sciences of Rural Federal University of the Amazon UFRA in Belém, PA.

\subsection{Soil Sampling}

The experimental plots were formed with soil collected in the $0-20 \mathrm{~cm}$ at an arable layer of a typical dystrophic Yellow Oxisol (Embrapa, 2013), submitted to chemical analysis according to Embrapa (2011).

\subsection{Soil Analysis}

pH was determined every 30 days using a 1:2.5 sol-liquid glass electrode in suspension. The fertilizers used were Urea as nitrogen source, Simple Superphosphate (SFS) and Arad as sources of phosphorus and Potassium chloride as of potassium that were applied to the soil before or after sowing of the grass (Brachiaria brizantha cv. Xaraés), According to the treatments.

As a criterion for the determination of the need for soil correction, a calculation was made for aluminum saturation corresponding to $3 \mathrm{t} \mathrm{ha}^{-1}$ of dolomitic limestone, according to Silva (2003), considering $96 \%$ relative total neutralization power (PRNT). Each vessel was $7.5 \mathrm{~g}$ according to each specific treatment.

The soil was incubated for a period of 30 days maintaining the humidity near the soil field capacity, with limestone to correct the acidity. Based on the soil analyzes, the fertilization was performed following the recommendation of $100 \mathrm{~kg} \mathrm{~N} h a^{-1}, 80 \mathrm{~kg} \mathrm{P}_{2} \mathrm{O}_{5} \mathrm{ha}^{-1}$ and $60 \mathrm{~kg} \mathrm{~K}_{2} \mathrm{O} \mathrm{ha}^{-1}$ (Cravo et al., 2007), which corresponded, respectively, The following quantities; $0.6 \mathrm{~g} / \mathrm{vessel}, 1.00 \mathrm{~g} / \mathrm{vessel}$ and $0.35 \mathrm{~g} / \mathrm{vessel}$. Implantation fertilization was performed in all treatments. In the treatments that were used the Arad, there was no application of the simple superphosphate, being applied $0.6 \mathrm{~g} /$ Arad vessel.

A completely randomized experimental design was used, with six treatments: soil only (control/T1); Soil + liming (T2); Soil + Arad 30 days before planting (T3); Soil + Arad in planting (T4); Soil + Arad + liming 30 days before planting (T5) and soil + Arad + liming in planting (T6), distributed in five replications, totaling 30 experimental units.

Twenty seeds of Brachiaria brizantha cv. Xaraés per pot with $8 \mathrm{~L}$ capacity, with germination beginning six days after sowing. In the 15 days after germination, thinning was performed, leaving nine plants per pot. Soil moisture was maintained at $70 \%$ of the total soil pore volume by daily weighing of the pots, adjusting the weight with distilled water.

Three cuts were performed to determine the biometric variables plant height (HP), number of leaves (NL), shoot fresh matter (SFM) and shoot dry matter (FDM). The first cut occurred at 45 days after germination, the second 30 days after the first and the third 30 days after the second, agreeing with the recommendations of the main seed suppliers of Xaraés, which affirmed the ideal period of 25 to 30 days of rest .

The SFM was determined by weighing the fresh material at the time of plant cutting, cutting was performed at 6 $\mathrm{cm}$ from the soil. Then, the material was packed in paper bags and fed to the forced circulation air oven at $65^{\circ}$ until constant weight was reached in 72 hours, obtaining FDM. 
The HP was obtained using a graduated ruler, from $6 \mathrm{~cm}$ from the soil to the curvature of the last fully expanded leaf; The NL was obtained from the direct counting of the same ones, considering the leaf those that already presented their final format, being disregarded the leaflets at launch. All the data were analyzed by means of the analysis of variance and submitted to the test of average (Tukey) test at $5 \%$ of probability using statistical package SISVAR 5.3 (Ferreira, 2011).

\section{Results and Discussion}

\subsection{Soil Characterization}

The $\mathrm{pH}$ before implantation of the experiment led the soil at the high acidity level (Table 1), according to the classification of Ribeiro et al. (1999). After application of the treatments, the $\mathrm{pH}$ values increased with the exception of the control (Figure 1), and at the end of the experiment the vessels with only natural phosphate (T2 and T3) increased the acidity for the average classification, Liming made the acidity weak (T2 and T6) to neutral (T5).

Table 1. Chemical characterization of the Yellow Latosol $(0-20 \mathrm{~cm}$ before the installation of the experiment)

\begin{tabular}{llllllllll}
\hline Sample & $\mathrm{pH}\left(\mathrm{H}_{2} \mathrm{O}\right)$ & $\mathrm{pH}(\mathrm{KCl})$ & $\mathrm{Ca}^{2+}$ & $\mathrm{Mg}^{2+}$ & $\mathrm{H}+\mathrm{Al}$ & $\mathrm{C}$ & $\mathrm{P}$ & $\mathrm{N}^{*}$ & $\mathrm{~K}^{*}$ \\
\hline \multirow{2}{*}{$0-20 \mathrm{~cm}$} & 4.63 & 4 & $--------\mathrm{cmol}_{\mathrm{c}} \mathrm{dm}^{-3}--------$ & $--\mathrm{g} \mathrm{dm}^{-3}--$ & $----------\mathrm{mg} \mathrm{dm}^{-3}$---------- \\
\hline
\end{tabular}

Note. ${ }^{*}$ Extracted by the Mehlich method.

It is important to note that the natural phosphate of Arad, even in the absence of liming, raised the $\mathrm{pH}$ to close to 6.0 (Figures 1C and 1D). Results similar to this were obtained in acid soils by Luchini et al. (2012), an effect attributed to the presence of calcium carbonate in Arad.

\section{$3.2 \mathrm{pH}$ Variations due to Treatments}

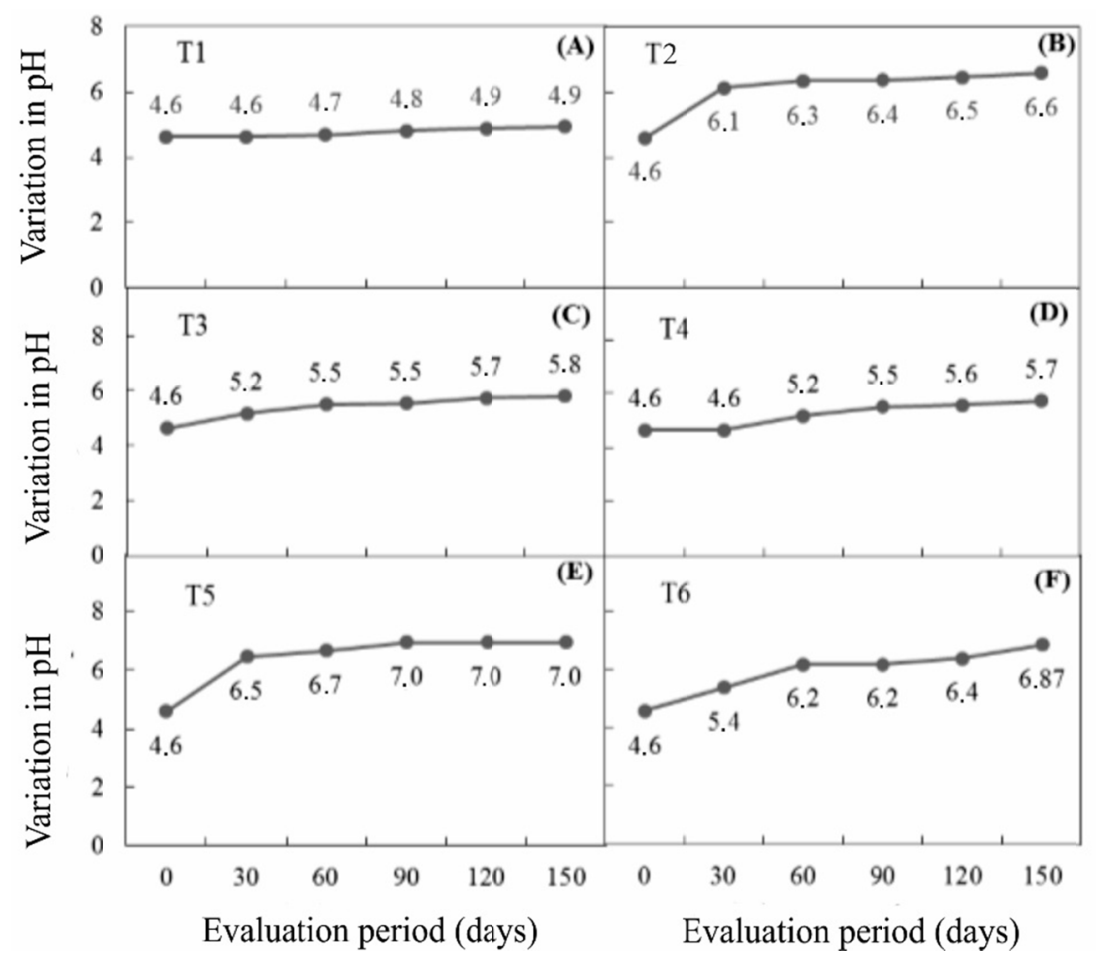

Figure 1. Effects of treatments only soil (T1); soil + liming (T2) soil + Arad 30 days before planting (T3); Soil + Arad in planting (T4); Soil + Arad + liming 30 days before planting (T5) and soil + Arad + planting liming (T6) at soil $\mathrm{pH}$ with Brachiaria brizantha $\mathrm{cv}$. Xaraés. Results are the mean \pm deviation of five replicates 
Treatments that received limestone, alone, and limestone added to Arad 30 days before planting, showed a rapid increase in $\mathrm{pH}$ (Figures 1B and 1E). However, it was possible to verify that in the treatments with the application of the Arad 30 days before and 30 days after the planting the increase occurred in a slower and more uniform way (Figures 1C and 1D). The combination of limestone and Arad in planting provided a gradual and linear increase in $\mathrm{pH}$ (Figure 1F). In the treatment that received the combined limestone with Arad 30 days before planting the highest $\mathrm{pH}$ value (7.0) was obtained in the last period (Figure 1E). We can evaluate that at 30 days of incubation, the $\mathrm{pH}$ with a level of 6.5 , can already be considered optimal for the main commercial crops. This result can be attributed to the joint action of limestone with Arad in soil correction.

Despite the increase in $\mathrm{pH}$ in all applied treatments, it was verified that in the treatment with only soil and Arad applied in the planting, the effect occurred more slowly, with better responses around 60 days after the application. This may have occurred due to the slow solubilization of the natural phosphate from Arad, as it was later applied in relation to the other treatments.

According to Ronquim (2010), the neutralization of soil acidity occurs because the limestone applied to the soil forms the $\mathrm{Ca}^{2+}, \mathrm{Mg}^{2+}$ and $\mathrm{HCO}_{3}{ }^{-}$ions, reacts with water to form hydroxyl $(\mathrm{OH})$, water and carbon dioxide $\left(\mathrm{CO}_{2}\right)$ ions formed by dissolution of calcium carbonate and magnesium in the composition of limestone and Arad.

Other work carried out in the region with yellow Oxisol presented similar results, in which the application of limestone promoted increase of soil $\mathrm{pH}$ (Cravo, 2012), demonstrating that liming is important in acid soils. As soil $\mathrm{pH}$ increases, it decreases or eliminates the phytotoxicity of $\mathrm{Al}$ and $\mathrm{Mn}$, provides $\mathrm{Ca}$ and $\mathrm{Mg}$, and increases the availability of $\mathrm{P}$ among other elements essential to plant maintenance.

The lime supply, added to the application of Arad in the plantation and 30 days before, provided a significant increase in the $\mathrm{pH}$ values of the soil, although the other treatments also had a significant elevation. As a result, increases in the HP and NL variables were observed in the three cutting stages of the Xaraes grass, differently from the treatment without soil correction, resulting in constant $\mathrm{pH}$ values maintaining the soil at acid levels.

\subsection{Phytometric Evaluation}

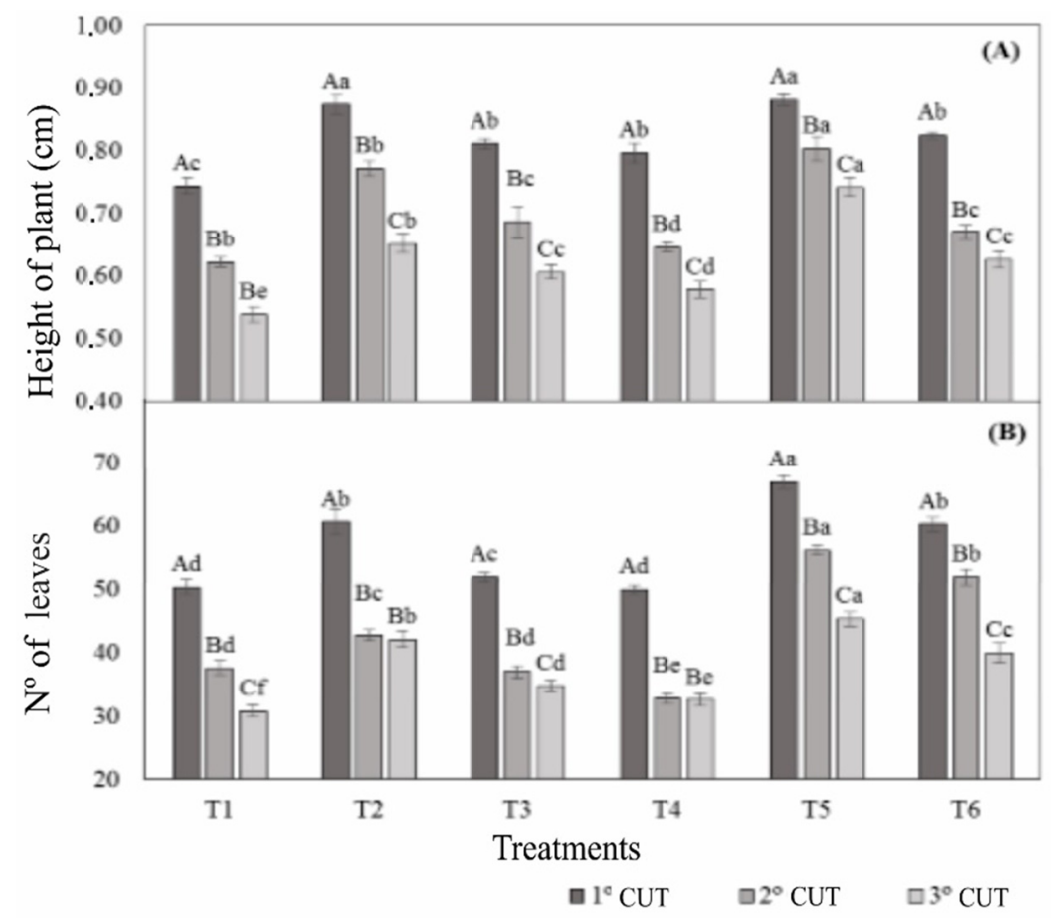

Figure 2. Effects of the addition of limestone and Arad at plant height and number of leaves in Brachiaria brizantha cv. Xaraés. Average \pm deviation of soil treatment only (T1); soil + liming (T2) soil + Arad 30 days before planting (T3); Soil + Arad in planting (T4); Soil + Arad + liming 30 days before planting (T5) and soil + Arad + liming at planting (T6) planted with Brachiaria brizantha cv. Xaraés. Upper case letters differentiate between cuts and lower case letters differentiate between treatments 
All the cuts presented differences between the treatments (Figure 2), except for the number of leaves for the second and third cuts of treatments T2 and T4, which were considered statistically equal (Figure 2B).

In general, in the first cut, it was verified for HP that the treatments with addition of limestone obtained more significant increments, where the variable height in the presence of limestone was higher in $17.5 \%$ in the T2 treatment and in $18.9 \%$ In the T5 treatment, when compared with the T1, control treatment in which there was no supply of limestone. Behavior similar to this was verified for the other cuts (Figure 2A).

Similarly, observed in the behavior of the variable HP is verified for the variable NL, in which greater increases were obtained in the treatments in which the limestone was used in combination with the Arad in the reduction of soil acidity. However, no significant differences were observed between the first and second cuts in T2 and T4 treatments (Figure 2B). However, it is noticed that the presence of limestone was important for the best performances.

The increments of SFM and FDM were significantly influenced by the application of limestone. When limestone + Arad was used on the day of planting (T5), the dry matter yield increased up to $35 \%$ in relation to the control treatment (Figure 3).

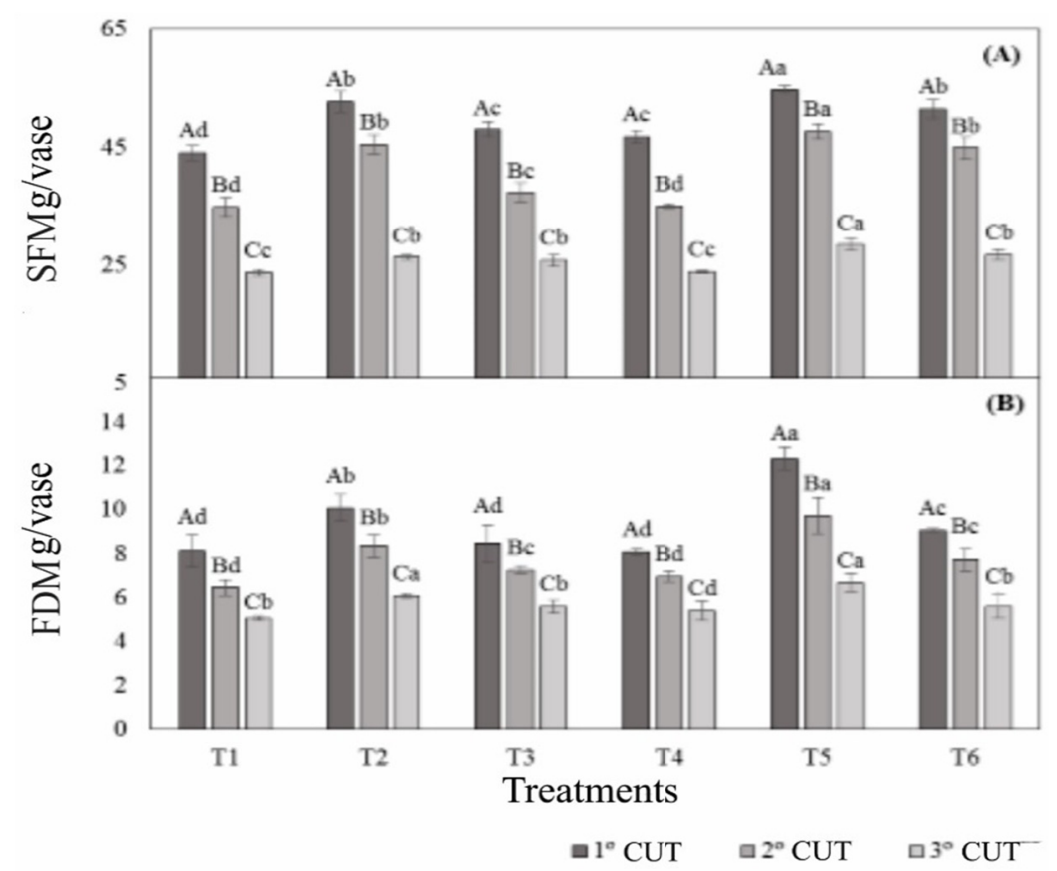

Figure 3. Effects of liming and phosphorus sources on shoot dry mass and fresh mass of Brachiaria brizantha aerial part. Average \pm deviation of soil treatment only (T1); soil + liming (T2) soil + Arad 30 days before planting (T3); Soil + Arad in planting (T4); Soil + Arad + liming 30 days before planting (T5) and soil + Arad + liming at planting (T6) planted with Brachiaria brizantha cv. Xaraés Capital letters differentiate between cuts and lowercase letters differentiate between treatments

The production of SFM and FDM presented better results with the application of limestone in conjunction with Arad 30 days before planting. The production of SFM and FDM was more significant in the first cut with higher increments than the others in all treatments. In T1 treatment the first, second and third cuts were superior to their respective cuts in T5 treatment, presenting 24.26\%,36.67\% and 20.25\%, respectively (Figure 3).

According to Costa et al. (2004), under unfavorable conditions, such as acidic soils or even the absence of nutrient replacement in the soil, a temporary paralysis of root system growth could occur, which would reduce the rate of forage growth, consequently The production of SFM and FDM. In this context, the increase in soil fertilization represents an efficient way to increase forage production, increasing the grass support capacity, increasing animal production per area and consequently higher productivity of livestock (Barcelos, 2011). 
Benett et al. (2009), evaluating the effect of different doses of phosphorus in the form of natural phosphate Arad in the production of dry mass of Brachiaria brizantha cv. Marandu observed that the increment of the phosphorus doses increased the dry mass and pasture height of Brachiaria brizantha cv. Marandu.

Guedes et al. (2009) evaluating the growth of Brachiaria brizanta Stap. Cv Marandu on different doses of the natural phosphate Arad and triple superphosphate, found that the doses of natural phosphate had a significant effect under the variables of dry mass of shoot and root, besides the number of tillers. These data collaborate with Bonfim-Silva et al. (2012) that verified changes in the morphological and productive characteristics of the Marandu grass when they were submitted to increasing doses of natural reactive phosphate.

In this work, it was verified that liming was able to increase both dry and fresh mass production, besides reducing soil acidity and providing $\mathrm{Ca}$ and $\mathrm{Mg}$ to the plants. Therefore, these benefits have resulted in higher yields of Xaraés grass compared to plants under acid soil conditions in the control treatment (T1). In general, the forage production was significantly higher in the first cut with successive reductions observed in the other cuts, probably due to the absence of nutrient replacement, since the Xaraés grass production was verified only with The application of the fertilization of foundation, in a different situation the other cuts could present considered additions in prod.

\section{Conclusions}

Natural Arad phosphate increased soil $\mathrm{pH}$, which was more evident when combined with lime, favoring plant development.

Correction of soil acidity and fertilization with natural phosphate should be antecedent to the planting for the greater forage production of Brachiaria brizantha $\mathrm{cv}$. Xaraes.

\section{References}

Alves, S. J., Moraes, A. de, Canto, M. W. do, Sandini, I., \& EMBRAPA. (2015). Espécies forrageiras recomendadas para produção animal (pp. 4-8). Retrieved from http://http://www.fcav.unesp.br/Home/ departamentos/zootecnia/ANACLAUDIARUGGIERI/especies_forrageiras.pdf

Barcelos, A. F., Lima, J. A. de, Pereira, J. F., Guimarães, P. T. G., Evangelista, A. R., \& Gonçalves, C. C. M. (2011). Fertilization of grasses of the genus Brachiaria (p. 84). Belo Horizonte: EPAMIG. Retrieved from http://www.agrisus.org.br/arquivos/Epamigbraquiaria.pdf

Benett, C. G. S., Silva, K. S., Yamashita, O. M., Filho, M. C. M. T., Garcia, M. de P., Nakayama, F. T., \& Buzetti, S. (2009). Production of Brachiaria brizantha under increasing doses of phosphorus. Omnia Exatas, 2(1), $17-25$.

Bonfim-Silva, E. M., Santos, C. C., Farias, L. N., Vilarinho, M. K. C., Guimarães, L. S. E., \& Silva, T. J. A. (2012). Morphological and productive characteristics of marandu grass fertilized with reactive natural phosphate in cerrado soil. Revista Agro@mbiente On-line, 6(2), 166-171. https://doi.org/10.18227/19828470ragro.v6i2.756

Corrêa, L. de A. (2002). Agronomic Characteristics of the Principal Tropical Forage Plants. Press Release Embrapa. São Carlos SP, Brazil. Retrieved from http://www.infoteca.cnptia.embrapa.br/bitstream/doc/ 45627/1/PROCIComT35LAC2002.00004.pdf

Costa, N. de L. (2004). Pasture formation, management and recovery in Rondônia (p. 219). Porto Velho: Embrapa Rondônia. Retrieved from http://www.infoteca.cnptia.embrapa.br/bitstream/doc/706944/1/livro pastagens.pdf

Costa, N. de L., Magalhães, J. A., Towsend, C. R., \& Paulino, V. T. (2004). Physiology and management of forage plants (p. 27). Porto Velho: Embrapa Rondônia. Embrapa Rondônia. Retrieved from http://www.infoteca.cnptia.embrapa.br/infoteca/bitstream/doc/916005/1/doc85plantasforrageiras.pdf

Costa, N. de L., Paulino, V. T., Magalhães, J. A., Rodrigues, A. N. Z., Bendahan, A. B., Nascimento, L. E. da S., \& Fernandes, R. C. P. (2012). Response of Brachiaria brizantha cv. Xaraés at liming levels. PUBVET, Londrina, 6(13), Article 1340. Retrieved from https://www.alice.cnptia.embrapa.br/alice/bitstream/doc/ 939375/1/apiRespostadebrachiaria.pdf

Cravo, M. da S., Smyth, T. J., \& Brasil, E. C. (2012). Liming in yellow latosol distrophic of the amazon and its influence on soil chemical attributes and the productivity of annual cultures. Revista Brasileira de Ciências do Solo, 36(2), 895-907. https://doi.org/10.1590/S0100-06832012000300020 
Cravo, M. S., Viégas, I. de J. M., \& Brasil, E. C. (2007). Fertilizer and Liming Recommendations for the State of Pará (pp. 153-155). Belém, PA: Embrapa Amazônia Oriental.

Embrapa (Empresa Brasileira de Pesquisa Agropecuária). (2011). National Soil Research Center. Manual of methods of soil analysis (2nd ed.). Rio de Janeiro: Embrapa Solos.

Ernani, P. R., Steckling, C., \& Bayer, C. (2001). Soil chemical characteristics and dry matter yield of maize according to the method of application of phosphate in two levels of acidity. Revista Brasileira de Ciências do Solo, 25(4), 939-946. https://doi.org/10.1590/S0100-06832001000400017

Ferreira, D. F. (2011). Sisvar: a computer statistical analysis system. Ciência e Agrotecnologia, 35(6), 1039-1042. https://doi.org/10.1590/S1413-70542011000600001

Ferreira, D. J., \& Zanine, A. M. (2007). Importance of cultivated pasture in Brazilian beef cattle production. Revista Eletrônica de Veterinária, 8(3), 1-18.

Fontoura, S. M. V., Vieira, R. C. B., Bayer, C., Ernani, P. R., \& Moraes, R. P. (2010). Technical efficiency of phosphate fertilizers in oxisol under no-tillage. Revista Brasileira de Ciências do Solo, 34(6), 1907-1914. https://doi.org/10.1590/S0100-06832010000600015

Galvão, J. R., Tofoli, R. de C. Z., Alves Filho P. P. da, Pinheiro, D. P., \& Galate, R. dos S. (2014). Sources of phosphorus and base saturation in the production of marandu grass in yellow latosol. Revista Verde de Agroecologia e Desenvolvimento Sustentável, 9(3), 198-204.

Guedes, E. M. S., Fernades, A. R., Lima, E. do V., Gama, M. A. P., \& Silva, A. L. P. da. (2009). Natural Arad phosphate and liming and the growth of Brachiaria brizantha under increasing doses of phosphorus. Revista Ciências Agrarias, 52(1), 117-129.

Kaminski, J., \& Peruzo, G. (1997). Efficacy of reactive natural phosphates in culture systems (p. 31). Santa Maria: Núcleo Regional da Sociedade Brasileira de Ciência do Solo.

Luchini, I., Tiritan, C. S., Foloni, J. S. S., \& Santos, D. H. (2012). Phosphorus available in acid and corrected soils with soluble, reactive and natural phosphate application. Scientia Agraria Paranaensis, 11(1), 82-94. https://doi.org/10.18188/1983-1471/sap.v11n1p82-94

Raij, B. V., \& Quaggio, J. A. (1984). Efficient use of limestone and gypsum in agriculture, Brasília, 1984 (pp.323-346). Anal... Brasília: EMBRAPA-DEP.

Ribeiro, A. C., Guimarães, P. T. G., \& Alvarez, V. V. H. (1999). Recommendations for the use of correctives and fertilizers in Minas Gerais (5th Aproximação). Viçosa, Brasil: CFSEMG.

Ronquim, C. C. (2010). Soil fertility concepts and proper management for tropical regions. Embrapa Monitoramento por Satélite, Campinas, SP, Brazil. Retrieved from https://ainfo.cnptia.embrapa.br/digital/ bitstream/item/31004/1/BPD-8.pdf

Silva, S. B. (2003). Soil analysis (p. 152). Belém, PA: Universidade federal rural da Amazônia.

Teixeira, G., Fernandes, A. R., Galvão, J. R., Silva, V. F. A., \& Melo, N. C. (2014). Arad phosphate, NPK and liming on corn crop in degraded pasture area. Revista Caatinga, 27(2), 124-131.

Viégas, I. de J. M., Cardoso, A., Viégas, R. M. F., \& Albuquerque, F. A. B. (1988). Liming and splitting of phosphatic fertilization on rubber tree rootstocks (Research Bulletin, 6). Belém: EMBRAPA-UEPAE. Retrieved from https://www.infoteca.cnptia.embrapa.br/infoteca/bitstream/doc/382008/1/BelemBP6.pdf

\section{Copyrights}

Copyright for this article is retained by the author(s), with first publication rights granted to the journal.

This is an open-access article distributed under the terms and conditions of the Creative Commons Attribution license (http://creativecommons.org/licenses/by/4.0/). 